\title{
ANALISIS TINGKAT KEPATUHAN PEMAKAIAN ALAT PELINDUNG DIRI MAHASISWA PROFESI DOKTER GIGI DI RUMAH SAKIT GIGI DAN MULUT UNSOED
}

\author{
Ina Permata Dewi ${ }^{*}$, Wiwiek R. Adawiyah'1, Lantip Rujito \\ ${ }^{1}$ Program Pascasarjana Magister Manajemen Universitas Jendral Soedirman Purwokerto \\ *E-mail corresponding author: inapermatadewi08@gmail.com
}

\begin{abstract}
Abstrak
Tujuan penelitian ini adalah untuk menentukan tingkat kepatuhan penggunaan alat pelindung diri untuk mahasiswa kedokteran gigi di Rumah Sakit Gigi Universitas Jenderal Soedirman pada tahun 2019. Metode penelitian ini adalah kuantitatif dan pendekatannya adalah cross sectional yang bertujuan untuk mengetahui faktor-faktor terkait kepatuhan penggunaan perlindungan pribadi peralatan untuk mahasiswa kedokteran gigi di Rumah Sakit Gigi Universitas Jenderal Soedirman Purwokerto (RSGM Unsoed). Populasi penelitian adalah siswa gigi di RSGM Unsoed tahun IX-XIII dengan sampel 111 siswa menggunakan simple random sampling. Pengambilan data penelitian menggunakan kuesioner dan lembar observasi sebagai ukuran penelitian. Analisis data penelitian yang digunakan adalah analisis Somers'd. Hasil penelitian menunjukkan bahwa ada hubungan antara usia dan kepatuhan penggunaan APD dengan nilai $p=0,001$. Tidak ada korelasi antara masa kerja dan kepatuhan penggunaan APD dengan nilai $p=0,74$. Ada hubungan pengetahuan kepatuhan penggunaan APD dengan nilai $p=$ 0,008 . Ada hubungan sikap terhadap kepatuhan penggunaan APD dengan nilai $p=0,001$. Ada hubungan ketersediaan fasilitas dengan kepatuhan penggunaan APD dengan nilai $p=0,000$. Ada hubungan pelatihan kepatuhan penggunaan APD dengan nilai $p=0,003$. Ada hubungan pengendalian terhadap kepatuhan penggunaan APD dengan nilai $p=0,001$. Kepatuhan mahasiswa kedokteran gigi RSGM Unsoed dalam penggunaan alat pelindung diri (APD) masih harus ditingkatkan dengan sosialisasi dan pengawasan berkala oleh RSGM Unsoed untuk melindungi siswa profesional dari risiko penularan infeksi di rumah sakit.
\end{abstract}

Kata kunci: Kepatuhan, Masa Kerja, Alat Pelindung Diri

\begin{abstract}
The objective of this study was to determine the level of compliance of the use of personal protective equipment for dental students at the Dental Hospital of General Soedirman University in 2019. The method of the study was quantitative and the approach was cross sectional aiming to find out related factors of compliance of the use of personal protective equipment for dental students at the Dental Hospital of General Soedirman University of Purwokerto (RSGM Unsoed). Population of the study was the dental students at RSGM Unsoed year IX-XIII with a sample of 111 students using simple random sampling. Retrieval of research data was using questionnaires and observation sheets as a measure of research. Analysis of the research data used was the analysis of Somers'd. The result of the study showed that there was a relationship between the age and the compliance of the use of PPE with a value of $p=0.001$. There was no correlation between years of service and the compliance of the use of PPE with a value of $p=0.74$. There was a relationship of knowledge of compliance of the use of PPE with a value of $p=0.008$. There was a relationship of attitudes toward compliance of the use of PPE with a value of $p=0,001$. There was a relationship of availability of facilities to compliance of the use of PPE with a value of $p=0.000$. There was a relationship of training of compliance of the use of PPE with the value of $p=0.003$. There was a relationship of controlling towards compliance of the use of PPE with the value of $p=0.001$. The compliance of dental students of RSGM Unsoed in the use of personal protective equipment (PPE) still has to be improved with periodic socialization and supervision by RSGM Unsoed to protect professional students from the risk of infection transmission in the hospital.
\end{abstract}

Keywords: Compliance, Years of Service, Personal protective equipment 


\section{Pendahuluan}

Rumah sakit merupakan institusi pelayanan kesehatan yang kompleks, padat pakar serta padat modal. Rumah sakit juga menggunakan banyak peralatan berteknologi tinggi, bahan, serta obat-obatan yang berbahaya dan para tenaga kesehatan di rumah sakit beresiko untuk terpapar terhadap bahan berbahaya yang dapat menimbulkan efek bagi terhadap status kesehatan mereka (Zaenab, 2012).

Tenaga kesehatan di rumah sakit berisiko tinggi untuk terinfeksi penyakit yang dapat mengancam kesehatan dan keselamatannya saat bekerja. WHO (World Health Organization) mencatat kasus infeksi nosokomial di dunia seperti penularan Hepatitis B sebanyak 66.000 kasus, hepatitis C 16.000 kasus, dan 1000 kasus penularan HIV (WHO, 2004). Di Indonesia sendiri angka infeksi nosokomial masih mencapai $15,74 \%$ yang masih tergolong tinggi dibandingkan dengan negara maju yang berkisar antara 4,8-15,5\% (Firmansyah, 2007).

Rumah sakit harus mempunyai suatu program yang dapat melindungi tenaga kesehatan maupun pasien di rumah sakit agar terhindar dari bahaya infeksi yang salah satunya dengan melaksanakan kegiatan Pencegahan dan Pengendalian Infeksi di Rumah Sakit. Pencegahan dan pengendalian penyakit infeksi di rumah sakit dapat dilakukan dengan meningkatkan perilaku kewaspadaan standar meliputi kebersihan tangan, penggunaan APD, pencegahan luka akibat benda tajam, pengelolaan limbah yang aman, pembersihan, desinfeksi dan sterilisasi peralatan perawatan pasien, dan pembersihan serta desinfeksi lingkungan yang dilakukan oleh tenaga kesehatan untuk mengurangi resiko penyebaran infeksi (WHO, 2004).

Green menyatakan bahwa perilaku kepatuhan seseorang dipengaruhi oleh banyak faktor, yang pertama yaitu faktor predisposisi (predisposing factor) yang meliputi usia, masa kerja, pengetahuan, sikap, sistem budaya, serta tingkat pendidikan. Faktor kedua yaitu faktor pemungkin (enabling factor) yang mencakup sarana dan prasarana/fasilitas. Faktor ketiga yaitu faktor penguat (reinforcing factor) yang meliputi sikap petugas kesehatan, dan peraturan yang berlaku (Notoadmodjo, 2007).

Rumah Sakit Gigi dan Mulut Universitas Jenderal Soedirman serupakan rintisan rumah sakit pendidikan bagi mahasiswa profesi yang sedang menempuh pendidikan profesi dokter gigi di Universitas Jenderal Soedirman yang berkewajiban untuk menyelenggarakan kegiatan pencegahan dan pengendalian infeksi dan bertanggung jawab memberikan pelatihan yang tepat bagi seluruh petugas kesehatan untuk dapat mencegah penularan infeksi (Souza, 2006).

Dalam pelaksanaanya, tingkat kepatuhan tenaga kesehatan dalam melaksanakan kewaspadaan standar terutama alat pelindung diri masih kurang, dan tentunya dapat membahayakan bagi para petugas kesehatan untuk dapat tertular infeksi di rumah sakit. Menurut laporan monitoring Tim Pencegahan dan Pengendalian Infeksi di Rumah Sakit Gigi dan Mulut Universitas Jenderal Soedirman rata rata kepatuhan penggunaan alat penggunaan alat pelindung diri pada di tahun 2018 mahasiswa profesi dokter gigi rata-rata sebesar 88,4\% (RSGM, 2018). Angka tersebut masih belum memenuhi standar indikator mutu di rumah sakit, dimana diharapkan indikator mutu sebesar 100\%. Berdasarkan hal tersebut, peneliti tertarik untuk meneliti tentang tingkat kepatuhan penggunaan alat pelindung diri pada mahasiswa profesi dokter gigi di Rumah Sakit Gigi dan Mulut Universitas Jenderal Soedirman tahun 2019.

\section{TINJAUAN PUSTAKA \\ Kepatuhan}

Kepatuhan berasal dari kata patuh yang memiliki arti suka menurut perintah, taat pada perintah, sedangkan kepatuhan adalah perilaku sesuai aturan dan berdisiplin (Sugiyono, 2008). Kepatuhan dalam lingkup tenaga kesehatan mengandung arti bahwa seseorang tenaga kesehatan memiliki kesadaran untuk dapat memahami dan menggunakan peraturan kesehatan yang berlaku, mempertahankan tertib terhadap pelayanan kesehatan serta menegakkan kewaspadaan standar.

Kepatuhan tenaga medis dan paramedis dalam melaksanakan tugas sesuai standar prosedur operasional berpengaruh terhadap terjadinya infeksi nosokomial di rumah sakit atau fasilitas pelayanan kesehatan lainnya. Berdasarkan fenomena yang sering terjadi di lapangan, banyak tenaga kesehatan yang kurang atau tidak patuh melaksanakan prosedur kerja sesuai 
standar prosedur operasional. Hasil penelitian Masloman et al. (2015) menunjukkan bahwa pelaksanaan dan pengendalian infeksi di RSUD Dr. Sam Ratulangi Tondano belum berjalan sesuai dengan standar prosedur operasional. Pelaksanaan kewaspadaan standar yang belum berjalan sesuai dengan pedoman pencegahan dan pengendalian infeksi Kementerian Kesehatan.

Notoatmodjo (2014) menyatakan bahwa perilaku seseorang dilatarbelakangi oleh tiga pokok, yaitu faktor predisposisi (Predisposisi Factor) yang meliputi usia, masa kerja, pengetahuan, sikap. Faktor pemungkin (Enabling Factor) meliputi ketersediaan fasilitas. Faktor Pendorong (Reinforcing Factor) yang meliputi pengawasan dan pelatihan.

\section{Alat Pelindung Diri}

Alat pelindung diri (APD) merupakan suatu alat yang digunakan untuk melindungi diri atau tubuh terhadap bahaya kecelakaan kerja serta dapat mengurangi tingkat keparahan dari kecelakaan kerja yang terjadi, namun tidak menghilangkan ataupun mengurangi bahaya yang ada (Mulyanti, 2008). APD digunakan untuk melindungi petugas kesehatan dari resiko pajanan cairan tubuh pasien seperti darah, sekret, ekskreta, kulit yang tidak utuh dan selaput lendir pasien. Alat pelindung diri diperlukan dalam melaksanakan tindakan yang berisiko tinggi seperti pemeriksaan rutin, tindakan bedah, otopsi, ataupun perawatan gigi dimana menggunakan bor dengan kecepatan putar yang tinggi (Depkes, 2010).

Menurut Departemen Kesehatan Republik Indonesia (2018) dan Potter \& Perry (2011) jenis-jenis alat pelindung diri meliputi sarung tangan, pelindung wajah, penutup kepala, gaun pelindung, dan sepatu pelindung (pelindung kaki).

\section{Standar Operasional Prosedur}

Standar Operasional Prosedur (SOP) merupakan tahapan yang dibakukan dan yang harus dilalui untuk menyelesaikan suatu proses kerja tertentu (Potter\&Perry, 2009). SOP digunakan untuk memastikan bahwa kegiatan operasional organisasi atau perusahaan berjalan dengan lancar (Sailendra, 2015). SOP berisi urutan langkah melakukan suatu pekerjaan, apa yang dilakukan, bagaimana melakukan, kapan melakukan, dan siapa yang melakukan (Moekijat, 2008).

SOP merupakan pedoman pelaksanaan pekerjaan sesuai dengan fungsi yang dapat dijadikan alat penilaian kinerja di lingkup instansi yang didasarkan pada indikator-indikator teknis, administratif, dan prosedural sesuai tata kerja, prosedur kerja, dan sistem kerja pada unit kerja yang bersangkutan (Atmoko, 2012).

Menurut Laksmi \& Budiantoro (2008), SOP adalah dokumen yang berkaitan dengan prosedur yang dilakukan secara runtun untuk menyelesaikan suatu pekerjaan sehingga memperoleh hasil kerja yang efektif dari pekerja dengan biaya yang serendah-rendahnya. SOP terdiri dari manfaat, kapan dibuat atau direvisi, metode penulisan prosedur, serta dilengkapi oleh bagan flowchart di bagian akhir.

SOP penggunaan alat pelindung diri di Rumah Sakit Gigi dan Mulut Universitas Jenderal Soedirman disusun oleh Tim Pencegahan dan Pengendalian Infeksi Rumah Sakit Gigi dan Mulut Universitas Jenderal Soedirman dapat dijadikan panduan dalam menggunakan alat pelindung diri

\section{METODE PENELITIAN}

Penelitian ini menggunakan metode kuantitatif dengan pendekatan cross sectional, untuk tingkat kepatuhan penggunaan alat pelindung diri pada mahasiswa profesi dokter gigi di Rumah Sakit Gigi dan Mulut Universitas Jenderal Soedirman Purwokerto (RSGM Unsoed). Populasi penelitian ini adalah mahasiswa profesi dokter gigi di RSGM Unsoed angkatan IX-XIII dengan jumlah sampel 111 orang yang didapt dengan metode simple random sampling. kepatuhan mahasiwa profesi dokter gigi dalam menggunakan APD. Variabel independen yang diteliti pada penelitian ini adalah usia, masa kerja, pengetahuan, sikap, ketersediaan fasilitas, pelatihan dan pengawasan. Pengambilan data penelitian menggunakan kuesioner dan lembar observasi sebagai alat ukur penelitian. Analisis data penelitian yang digunakan adalah analisis Somers'd. 
HASIL ANALISIS

Gambaran Umum Responden

Distribusi responden menurut jenis kelamin

Penelitian ini dilakukan menggunakan teknik simple random sampling. Jumlah sampel pada penelitian ini sejumlah 111 responden, yang terdiri dari jenis kelamin laki-laki dan perempuan. Karakteristik responden berdasarkan jenis kelamin disajikan pada Tabel 4.1.

Tabel 1 Distribusi responden berdasarkan jenis kelamin

\begin{tabular}{lcc}
\hline $\begin{array}{l}\text { Jenis } \\
\text { Kelamin }\end{array}$ & Jumlah & $\begin{array}{c}\text { Persentase } \\
(\%)\end{array}$ \\
\hline Laki-laki & 26 & 23,4 \\
Perempuan & 85 & 76,7 \\
Total & 111 & 100,0 \\
\hline
\end{tabular}

Sumber: Data primer terolah, 2019

Tabel 1 menunjukkan bahwa sebagian besar responden pada penelitian ini berjenis kelamin perempuan dengan persentase sebesar 76,7\% dari 111 responden. Persentase responden dengan jenis kelamin laki-laki dalam penelitian ini adalah $23,4 \%$ dari keseluruhan responden.

Distribusi responden menurut rentang usia

Penelitian ini dilakukan kepada responden dengan variasi usia. Rentang usia pada penelitian ini dibagi menjadi 2, yaitu usia 20-25 tahun dan 26-30 tahun. Karakteristik responden berdasarkan rentang usia disajikan pada Tabel 2 .

Tabel 2 Distribusi responden berdasarkan rentang usia

\begin{tabular}{ccc}
\hline $\begin{array}{c}\text { Rentang Usia } \\
\text { (Tahun) }\end{array}$ & Jumlah & $\begin{array}{c}\text { Persentase } \\
\text { (\%) }\end{array}$ \\
\hline $20-25$ & 82 & 73.9 \\
$26-30$ & 29 & 26.1 \\
Total & 111 & 100 \\
\hline
\end{tabular}

Sumber: Data primer terolah, 2019

Tabel 2 menunjukkan bahwa responden dalam penelitian ini didominasi oleh responden pada rentang usia 20-25 tahun dengan persentase sebesar 73,9\%. Sedangkan responden dengan rentang usia 26-30 tahun berjumlah 26,1\% dari keseluruhan responden.

Distribusi Responden Berdasarkan Masa Kerja

Penelitian ini dilakukan kepada responden dengan variasi masa kerja. Masa kerja responden dalam penelitian ini dibagi menjadi 5 rentang masa kerja. Karakteristik responden berdasarkan rentang usia disajikan pada Tabel 3.

Tabel 3 Distribusi Responden Berdasarkan Rentang Masa Kerja

\begin{tabular}{ccc}
\hline $\begin{array}{c}\text { Rentang } \\
\text { Waktu } \\
\text { (Bulan) }\end{array}$ & Jumlah & $\begin{array}{c}\text { Persentase } \\
\text { (\%) }\end{array}$ \\
\hline$<6$ & 19 & 17.1 \\
$6-12$ & 12 & 10.8 \\
$12-18$ & 33 & 29.7 \\
$18-24$ & 10 & 9.0 \\
$24-30$ & 37 & 33.3 \\
Total & 111 & 100,0 \\
\hline \multicolumn{2}{l}{ Sumber: Data primer terolah, 2019 }
\end{tabular}


Tabel 3 menunjukkan bahwa sebagian besar responden dalam penelitian ini mempunyai masa kerja 24-30 bulan dengan persentase sebesar 33,3\% dan paling sedikit adalah responden dengan masa kerja 18-24 bulan dengan persentase sebesar 9\% dari keseluruhan responden.

\section{Uji Instrumen Penelitian}

Instrumen penelitian yang digunakan dalam penelitian ini berupa kuesioner dan dilakukan uji validitas serta reabilitas untuk menguji kevalidan dan konsistensi kuesioner. Uji validitas pada penelitian ini menggunakan korelasi Pearson dengan nilai signifikansi 0,05. Berdasarkan rumus $\mathrm{df}=\mathrm{n}-2$, diperoleh nilai $\mathrm{r}$ tabel sebesar 0,374 . Uji reliabilitas pada penelitian ini menggunakan metode Cronbach's Alpha. Instrumen penelitian dinyatakan reliabel apabila $\mathrm{r}$ hitung $>r$ tabel. Nilai $r$ tabel untuk responden sejumlah 111 yaitu 0,1848. Hasil uji validitas dan reliabilitas disajikan pada Tabel 4.

\begin{tabular}{ccc}
\multicolumn{3}{c}{ Tabel 4 Hasil Uji Validitas dan Reliabilitas } \\
\hline Variabel & $\begin{array}{c}\text { Jumlah } \\
\text { Item } \\
\text { Valid }\end{array}$ & $\begin{array}{c}\text { Cronbach's } \\
\text { Alpha }\end{array}$ \\
\hline Pengetahuan & 13 & 0,297 \\
Sikap & 13 & 0,552 \\
Ketersediaan & 10 & 0,687 \\
Fasilitas & 7 & 0,586 \\
Pelatihan & 7 & 0,610 \\
Pengawasan & 7 &
\end{tabular}

Tabel 4 menunjukkan bahwa semua item pertanyaan pada masing-masing variabel memiliki nilai $r$ hitung yang lebih tinggi daripada 0,374. Hal ini menunjukkan bahwa seluruh item pertanyaan yang diajukan dalam penelitian ini adalah valid. Hasil uji reliabilitas pada penelitian ini menunjukkan nilai alpha pada semua variabel lebih besar daripada $r$ tabel 0,1848. Hal ini menunjukkan bahwa semua pertanyaan pada masing-masing variabel dinyatakan reliabel.

\section{Analisis Univariat}

Analisis univariat pada penelitian ini menggambarkan deskripsi setiap variabel pada penelitian ini. Hasil statistik deskriptif penelitian ini disajikan pada Tabel 4.5.

Tabel 5 Ringkasan hasil analisis univariat

\begin{tabular}{lccccc}
\hline \multirow{2}{*}{ Variabel } & \multicolumn{5}{c}{ Kategori (\%) } \\
\cline { 2 - 6 } & $\begin{array}{c}\text { Sangat } \\
\text { Rendah }\end{array}$ & Rendah Sedang & Tinggi & $\begin{array}{c}\text { Sangat } \\
\text { Tinggi }\end{array}$ \\
\hline Pengetahuan & 0 & 0 & 10,8 & 67,6 & 21,6 \\
Sikap & - & 0 & 0 & 100 & - \\
Ketersediaan & - & 0 & 3,6 & 96,4 & - \\
Fasilitas & & 0 & & & \\
Pelatihan & - & 0 & 7,2 & 92,8 & - \\
$\begin{array}{l}\text { Pengawasan } \\
\text { Kepatuhan }\end{array}$ & - & 0 & 13,5 & 86,5 & - \\
APD & 0 & 0 & 1,8 & 73,9 & 24,3 \\
\hline
\end{tabular}

Sumber : Data Primer Terolah, 2019

Hasil rata-rata jawaban responden pada penelitian ini dibagi menjadi 3 klasifikasi yaitu rendah, sedang, dan tinggi. Pembagian rentang klasifikasi pada penelitian ini ditentukan dengan menggunakan angka indeks untuk memperoleh deskripsi tentang bagaimana tanggapan responden pada variabel yang diteliti. Angka indeks dihitung berdasar skor jawaban responden. Teknik scoring dalam penelitian ini adalah skor terkecil 1 dan terbesar 5. Dari skor tersebut, perhitungan indeksnya adalah menurut rumus berikut (Ferdinand, 2011): 
Interval $\quad=\underline{\text { Batas atas }- \text { Batas bawah }}$

$$
\begin{aligned}
& =\frac{5-1}{3} \\
& =1,3
\end{aligned}
$$

Angka atau skor jawaban responden dimulai dari angka 1 hingga 5, dengan menggunakan tiga kriteria maka diperoleh rentang sebesar 1,3 yang digunakan sebagai dasar interpretasi nilai indeks, yaitu: (Ferdinand, 2011)

$\begin{array}{ll}\text { Rendah } & =1-2,3 \\ \text { Sedang } & =2,31-3,6 \\ \text { Tinggi } & =3,61-5\end{array}$

Dari hasil analisis univariat dapat diketahui bahwa pengetahuan responden $10,8 \%$ dalam kategori sedang, 67,6\% memiliki pengetahuan yang tinggi dan 21,6\% responden memiliki pengetahuan yang sangat tinggi. Pada variabel sikap seluruh responden dikategorikan memiliki sikap yang tinggi dengan persentase $100 \%$. Ketersediaan fasilitas juga dikategorikan sedang dengan persentase 3,6\% dan tinggi sebesar $96,4 \%$. Variabel pelatihan terdapat 7,2\% responden yang terkategorikan sedang dan 92,8\% terkategorikan tinggi. Pada variabel pengawasan memiliki kategori sedang sebesar $13,5 \%$ dan tinggi sebesar $86,5 \%$. Sedangkan pada variabel kepatuhan terdapat 1,8\% responden yang memiliki kepatuhan sedang, 73,9\% memiliki kepatuhan tinggi dan 24,3\% memilki kepatuhan yang sangat tinggi.

\section{Analisis Bivariat}

Analisis bivariat dalam penelitian ini menggunakan menggunakan analisis korelasi Somers'd untuk mengetahui hubungan variabel bebas yaitu usia, masa kerja, pengetahuan, sikap, ketersediaan fasilitas, pelatihan dan pengawasan terhadap variabel terikat yaitu kepatuhan penggunaan alat pelindung diri. Hasil analisis korelasi disajikan pada Tabel 4.6.

Tabel 6. Hasil Analisis Korelasi antara Faktor Yang Behubungan dengan Kepatuhan

\begin{tabular}{clcc}
\hline \multirow{2}{*}{ No } & \multirow{2}{*}{ Parameter } & \multicolumn{2}{c}{ Korelasi } \\
\cline { 3 - 4 } & R & P \\
\hline 1. & Usia & $-0,248$ & 0,001 \\
2. & Masa kerja & $-0,140$ & 0,74 \\
3. & Pengetahuan & 0,201 & 0,008 \\
4. & Sikap & 0,207 & 0,001 \\
5. & Ketersediaan & 0,267 & 0,000 \\
& Fasilitas & 0,267 & 0,003 \\
6. & Pelatihan & 0,288 & 0,001 \\
7. & Pengawasan & \multicolumn{2}{c}{} \\
\hline \multicolumn{3}{c}{ Sumber : Data Primer Terolah, 2019 }
\end{tabular}

Tabel 6 menunjukkan hasil analisis korelasi variabel masa umur, pengetahuan, sikap, ketersediaan fasilitas, pelatihan dan pengawasan berhubungan dengan kepatuhan penggunaan alat pelindung diri dengan nilai $\mathrm{p}<0,05$. Hasil analisis korelasi menunjukan variabel masa kerja tidak berhubungan dengan kepatuhan penggunaan alat pelindung diri dengan nilai $p>0,05$.

Koefisien korelasi pada variabel sikap, ketersediaan fasilitas, pelatihan dan pengawasan bernilai positif yang menunjukan bahwa semakin tinggi nilai variabel tersebut maka semakin tinggi pula nilai kepatuhan penggunaan alat pelindung diri. Sebaliknya koefisien negatif pada variabel usia dan masa kerja menunjukan bahwa semakin tinggi usia dan masa kerja, maka kepatuhan penggunaan alat pelindung diri akan semakin rendah. 


\section{HASIL DAN PEMBAHASAN}

Penelitian ini melibatkan 111 responden mahasiswa profesi dokter gigi di Rumah Sakit Gigi dan Mulut Universitas Jenderal Soedirman Purwokerto dari total populasi sebesar 153 mahasiswa profesi dokter gigi angkatan IX - XIII. Populasi ini dipilih karena mahasiswa profesi angkatan IX - XIII masih menjalankan kegiatan praktek di Rumah Sakit Gigi dan Mulut Universitas Jenderal Soedirman Purwokerto. Sampel penelitian dipilih menggunakan metode simple random sampling agar seluruh anggota populasi mendapat kesempatan yang sama untuk menjadi sampel penelitian (Masyhuri, 2008).

Karakteristik responden berdasarkan jenis kelamin dalam penelitian ini didominasi oleh perempuan sejumlah $76,7 \%$ dari total populasi. Mayoritas mahasiswa profesi dokter gigi di Rumah Sakit Gigi dan Mulut Universitas Jenderal Soedirman Purwokerto didominasi oleh perempuan karena profesi dokter gigi merupakan profesi yang membutuhkan ketelitian serta estetika yang identik dengan perempuan. Menurut Balbeid (2018) sektor kesehatan masih lebih didominasi oleh jenis kelamin perempuan, tenaga tenaga kesehatan harus memiliki kemampuan untuk melakukan perawatan dan harus memiliki mother instinct yang lebih dimiliki oleh kaum perempuan.

Karakteristik responden berdasarkan usia didominasi oleh rentang usia 20-25 tahun dengan persentase sebesar $73,9 \%$ dari total populasi. Sedangkan responden dengan rentang usia 26-30 tahun sebesar 26,1\%. Besarnya persentase ini disebabkan karena mahasiswa profesi dokter gigi mayoritas merupakan mahasiswa angkatan 2011-2013 yang rata-rata berusia 20-25 tahun.

Karakteristik responden berdasarkan masa kerja dalam penelitian ini paling banyak merupakan responden dengan masa kerja 24-30 bulan dengan persentase 33,3\%. Responden dengan masa kerja 24-30 tahun ini merupakan mahasiswa profesi dokter gigi angkatan IX, yang merupakan angkatan dengan jumlah mahasiswa paling banyak yaitu sejumlah 52 orang.

\section{Analisis Bivariat}

Hubungan usia terhadap kepatuhan penggunaan alat pelindung diri

Hasil analisis korelasi untuk menguji hipotesis pertama (H1) pada penelitian ini menyatakan bahwa usia berhubungan dengan kepatuhan penggunaan alat pelindung diri. Hal ini menunjukan bahwa semakin bertambahnya usia mahasiswa profesi dokter gigi maka kepatuhan penggunaan alat pelindung diri semakin baik.

Hasil penelitian ini sesuai dengan penelitian yang dilakukan oleh Supiana (2013) dengan hasil bahwa terdapat hubungan signifikan antara usia dengan kepatuhan penggunaan alat pelindung diri pada bidan di pelayanan kebidanan RKIA Sadewa Yogyakarta. Hal ini juga sesuai dengan penelitian yang dilakukan oleh Apriliuana (2006) yang menyatakan bahwa terdapat hubungan yang sangat signifikan antara usia dengan perilaku penggunaan alat pelindung diri pada tenaga kesehatan di Rumah Sakit Umum Daerah Banjarbaru. Namun hasil penelitian ini tidak sejalan dengan penelitian yang telah dilakukan oleh Ibrahim (2009) yang menunjukan bahwa tingkat kepatuhan penggunaan alat pelindung diri antara usia lebih dari mean usia sama dengan usia yang kurang dari mean usia sehingga dapat dinyatakan bahwa tidak ada hubungan antara usia dengan perilaku kepatuhan pemakaian alat pelindung diri pada petugas laboratorium klinik kota Cilegon.

Kategori usia pada penelitian ini didasarkan pada pembagian usia menurut Departemen Kesehatan RI yaitu rentang usia 20-25 tahun yang tergolong sebagai remaja akhir dimana pada fase ini seseorang mulai memasuki fase perkembangan menjadi manusia yang lebih matang untuk memasuki usia dewasa. Pada rentang usia 26-30 tahun tergolong dalam fase dewasa awal dimana seseorang mulai untuk memasuki fase dewasa dan mulai belajar untuk lebih bertanggunggjawab terhadap orang lain (Depkes, 2009). Pada tahap dewasa awal ini kemampuan kognitif seseorang berada pada tahap prima yaitu saat seseorang akan lebih mudah untuk mempelajari, melakukan penalaran logis, berfikir kreatif, dan belum terjadi penurunan ingatan (Potter \& Perry, 2005). Bertambahnya usia seseorang akan mengakibatkan perubahan pada aspek psikis dan psikologis akibat pematangan fungsi organ sehingga taraf berpikir seseorang menjadi semakin matang dan dewasa (Mubarak, 2007). Bertambahnya usia seseorang 
juga akan menambah kedewasaan dan juga memiliki pengetahuan dan pengalaman lebih yang akan mempengaruhi perilakunya terutama perilaku dalam menggunakan alat pelindung diri karena responden menyadari betul pentingnya menggunakan alat pelindung diri yang baik agar dapat terhindar dari potensi penularan penyakit infeksi di rumah sakit.

Hubungan masa kerja terhadap kepatuhan penggunaan alat pelindung diri

Hasil analisis korelasi untuk menguji hipotesis kedua (H2) adalah nilai p 0,74 yang berarti masa kerja tidak berhubungan dengan kepatuhan penggunaan alat pelindung diri sehingga $\mathrm{HO}$ ditolak. Hasil penelitian ini sesuai dengan penelitian yang dilakukan oleh Ibrahim (2009), yang menunjukan bahwa tidak ada hubungan bermakna antara masa kerja dengan tingkat tingkat kepatuhan penggunaan sarung tangan pada petugas laboratorium klinik di Cilegon.

Hasil penelitian ini tidak sejalan dengan penelitian yang telah dilakukan oleh Wibowo (2013) dengan hasil bahwa terdapat hubungan signifikan antara masa kerja dan kepatuhan penggunaan sarung tangan saat tindakan invasif di ruang rawat inap RSUD Dr. H. Soewondo Kendal. Penelitian lain yang berlawanan yaitu penelitian yang dilakukan oleh Al Maweri (2015) yang menyatakan bahwa mahasiswa kedokteran gigi di Universitas Al Farabi, Riyadh, Saudi Arabia dengan masa kerja lebih lama memiliki tingkat kepatuhan pencegahan infeksi yang lebih tinggi dibanding mahasiswa tingkat awal.

Gibson (1997) menyatakan bahwa pengalaman berpengaruh terhadap perilaku dan prestasi kerja individu. Semakin lama masa kerja seseorang maka kecakapan akan meningkat karena telah menyesuaikan diri dengan pekerjaannya. Namun, Mulyaningsih (2013) menyatakan seseorang dengan masa kerja yang lebih lama kadang-kadang produktivitasnya menurun karena terjadi kebosanan sehingga tingkat kepatuhannya pun dapat menurun.

Dari hasil penelitian dapat dilihat bahwa kepatuhan mahasiswa profesi dokter gigi di Rumah Sakit Gigi dan Mulut Universitas Jenderal Soedirman Purwokerto tidak dipengaruhi oleh lama masa kerja atau masa menjalani profesi mereka. Baik pada responden dengan masa kerja yang lebih lama atau baru saja menjalani studi tidak terdapat perbedaan perilaku dalam menggunakan alat pelindung diri karena mereka sudah diberikan bekal pengetahuan pentingnya penggunaan alat pelindung diri dalam tindakan pencegahan infeksi. Mahasiswa profesi dokter gigi pada saat akan menjalankan masa studi sudah diberikan pelatihan mengenai pentingnya penggunaan alat pelindung diri dan peraturan yang berlaku di rumah sakit sehingga mereka sudah memiliki kesadaran yang tinggi untuk memberikan pelayanan dengan baik sesuai dengan peraturan yang berlaku di rumah sakit.

Hubungan pengetahuan terhadap kepatuhan penggunaan alat pelindung diri

Hasil pengujian hipotesis dalam penelitian ini menyatakan bahwa pengetahuan berhubungan dengan tingkat kepatuhan penggunaan alat pelindung diri dengan nilai p 0,008 yang menunjukan bahwa dengan semakin tinggi pengetahuan mahasiswa profesi dokter gigi mengenai alat pelindung diri, maka kepatuhan mahasiswa profesi dokter gigi dalam menggunakan alat pelindung diri semakin baik.

Hasil penelitian ini sejalan dengan penelitian yang dilakukan oleh Saputro (2015), yang menunjukan bahwa terdapat hubungan antara pengetahuan dengan penggunaan alat pelindung diri pada pekerja di Klaten. Penelitian yang dilakukan oleh Goje (2018) juga menyatakan bahwa terdapat hubungan antara pengetahuan dan penerapan universal precaution pada mahasiswa keperawatan dan kebidanan di Damaturu, Timur Laut Nigeria. Sebaliknya, pada penelitian yang dilakukan oleh Putra (2012), menyatakan bahwa bahwa tidak terdapat hubungan antara pengetahuan dengan kepatuhan penggunaan alat pelindung diri pada mahasiswa profesi di Universitas Indonesia. Penelitian yang dilakukan oleh Labrague (2012) terhadap mahasiswa profesi keperawatan di Filipina juga menunjukan bahwa tidak terdapat hubungan anatar pengetahuan dan penggunaan alat pelindung diri.

Menurut Bloom pengetahuan adalah domain yang sangat penting untuk membentuk tindakan seseorang (over behavior). Semakin tinggi pengetahuan kesehatan seseorang, maka kesadaran seseorang untuk berperan serta juga semakin tinggi (Notoatmodjo, 2007). Sedangkan Green menyatakan bahwa bertambahnya tingkat pengetahuan tidak selalu menyebabkan perubahan perilaku, namun hubungan positif kedua variabel tersebut sering 
terlihat dalam sejumlah penelitian yang dilakukan (Notoadmodjo, 2007). Pengetahuan tentang penggunaan alat pelindung diri penting dimiliki sebelum mengambil tindakan untuk menggunakan alat pelindung diri, tetapi kepatuhan penggunaan alat pelindung diri tidak akan terjadi begitu saja, kecuali saat seseorang mendapatkan pendorong yang lebih kuat untuk memotivasi seseorang bertindak sesuai pengetahuan yang dimiliki.

Tingkat pengetahuan mengenai alat pelindung diri mahasiswa profesi dokter gigi di Universitas Jenderal Soedirman tergolong tinggi, hal ini dikarenakan repsonden berasal dari kalangan intelektual dengan kondisi lingkungan belajar yang memadahi sehingga mempengaruhi pengetahuan responden terhadap alat pelindung diri. Responden mudah untuk memperoleh informasi mengenai alat pelindung diri dari buku, jurnal penelitian serta materi perkuliahan lain yang dapt meningkatkan pengetahuan para responden. Selain itu mahasiswa profesi dokter gigi di Rumah Sakit Gigi dan Mulut Universitas Jenderal Soedirman Purwokerto telah mendapatkan pelatihan tentang pencegahan dan pengendalian infeksi yang mencakup penggunaan alat pelindung diri di awal sebelum mereka menjalani masa studi dan peatihan berkala yang diilakukan oleh Tim Pencegahan dan Pengendalian Infeksi Rumah Sakit. Menurut Katherine (2010) lembaga pendidikan berperan besar mengajarkan prinsip pencegahan infeksi yang meliputi penggunaan alat pelindung diri yang dapat memberikan dampak besar dalam pengetahuan mahasiswa profesi dokter gigi yang terkait dengan penggunaan alat pelindung diri.

\section{Hubungan sikap terhadap kepatuhan penggunaan alat pelindung diri}

Dari hasil uji hipotesis yang dilakukan dalam penelitian ini menunjukan bahwa terdapat hubungan antara sikap dengan kepatuhan penggunaan alat pelindung diri mahasiswa profesi dokter gigi di Rumah Sakit Gigi dan Mulut Universitas Jenderal Soedirman Purwokerto dengan nilai $\mathrm{p}$ 0,001. Bloom menyatakan bahwa perilaku merupakan salah satu faktor predisposisi yaitu salah satu faktor dalam diri individu dimana di dalamnya terdapat sikap dari individu.

Sikap dapat mempengaruhi kepatuhan seseorang dalam menggunakan alat pelindung diri di rumah sakit dikarenakan sikap seseorang akan merupakan awal terbentuknya perilaku (Dayakisni, 2003). Hal ini sesuai juga dengan penelitian yang dilakukan oleh Riyanto (2014) yang menyatakan bahwa terdapat hubungan antara faktor sikap dengan kepatuhan perawat dalam penggunaan APD di Rumah Sakit Sari Asih Serang Provinsi Banten. Sejalan pula dengan penelitian yang dilakukan oleh Baseer (2014) yang menyatakan bahwa sikap berkorelasi dengan kepatuhan penggunaan alat pelindung diri pada dokter gigi pada klinik gigi di Riyadh, Saudi Arabia. Sebaliknya, hasil penelitian tidak sejalan dengan penelitian yang dilakukan oleh Sihombing (2014), dengan hasil bahwa tidak terdapat hubungan antara sikap dengan dengan penggunaan alat pelindung diri. Penelitian Alharbi (2019) juga menyatakan tidak terdapat hubungan signifikan antara sikap dengan perilaku pencegahan infeksi pada mahasiswa kedokteran gigi di Universitas Raja Saud, Riyadh, Saudi Arabia.

Mahasiswa profesi di Rumah Sakit Gigi dan Mulut Universitas Jenderal Soedirman memiliki rata-rata sikap tinggi. Sikap yang tinggi ini menjadi dasar terbentuknya perilaku yang membuat kepatuhan penggunaan alat pelindung diri responden meningkat. Sikap dalam suatu pekerjaan penting untuk menjadi pertimbangan pengambilan keputusan yang baik yang akan menghasilkan sikap positif dan kemudian menjadi perilaku yang baik. Sikap postitif ini juga menunjukkan bahwa responden menggunakan alat pelindung diri karena mengetahui resiko yang akan timbul apabila tidak menggunakan alat pelindung diri dengan lengkap dan menghindari resiko penularan penyakit infeksi yang dapat terjadi.

Hubungan ketersediaan fasilitas terhadap kepatuhan penggunaan alat pelindung diri

Hasil penelitian ini menunjukan bahwa ketersediaan fasilitas memiliki nilai signifikansi sebesar 0,000 sehingga dapat disimpulkan bahwa ketersediaan fasilitas memiliki hubungan signifikan dengan kepatuhan penggunaan alat pelindung diri pada mahasiswa profesi dokter gigi di Rumah Sakit Gigi dan Mulut Universitas Jenderal Soedirman. Green menyatakan bahwa salah satu faktor yang mempengaruhi perilaku yaitu faktor pendukung (enabling factor) yang salah satunya yaitu ketersediaan fasilitas yang dalam hal ini yaitu tersedianya alat pelindung diri yang baik dan lengkap. Tersedianya alat pelindung diri ini merupakan salah satu cara untuk 
dapat memfasilitasi responden untuk dapat menggunakan alat pelindung diri dengan lengkap untuk melakukan tindakan perawatan.

Hal ini sejalan dengan penelitian yang dilakukan oleh Putri (2011) menyatakan bahwa terdapat hubungan antara ketersediaan fasilitas alat pelindung diri terhadap kepatuhan menggunakan alat pelindung diri sebagai salah satu penerapan kewaspadaan universal di RSUP DR. Djamil Padang. Penelitian lain yang mendukung yaitu penelitian yang dilakukan oleh Ibrahim (2009) yang juga menunjukan bahwa terdapat hubung ketersediaan fasilitas terhadap kepatuhan penggunaan sarung tangan petugas laboratorium klinik di Cilegon. Sebaliknya hasil penelitian ini tidak sesuai dengan penelitian yang dilakukan oleh Apriliuana (2016) yang menyatakan bahwa ketersediaan alat pelindung diri tidak berhubungan dengan kepatuhan penggunaan alat pelindung diri. Tidak sejalan pula dengan penelitian Wuisan (2017) pada perawat di RS Dr. Kandou Manado yang menunjukan bahwa tidak terdapat hubungan anatara ketersediaan fasilitas dengan kepatuhan perilaku pencegahan infeksi.

Ketersediaan fasilitas yang mudah diperoleh dan dapat dimanfaatkan merupakan hal yang penting untuk membentuk perilaku. Selalu tersedianya fasilitas yang mendukung akan memunculkan perilaku positif seseorang (Azwar, 1983). Rumah Sakit Gigi dan Mulut Universitas Jenderal Soedirman sebagai pusat pelayanan kesehatan gigi dan mulut di Purwokerto selalu berusaha menyediakan tersedianya fasiliatas alat pelindung diri bagi seluruh tenaga medis di rumah sakit, namun bagi klinik tempat mahasiswa profesi dokter gigi menjalankan studi, tidak semua alat pelindung diri disediakan mengingat jumlah mahasiswa yang cukup banyak dan selalu berganti dalam tiap periode, walaupun begitu mahasiswa tetap memiliki tingkat kepatuhan yan baik karena juga didukung oleh pengetahuan dan sikap yang baik pula sehingga membentuk perilaku kepatuhan yang baik pula (Notoatmojo, 2007).

Hubungan pelatihan terhadap kepatuhan penggunaan alat pelindung diri

Dari hasil analisis penelitian ini menunjukkan bahwa terdapat hubungan antara pelatihan terhadap kepatuhan penggunaan alat pelindung diri mahasiswa profesi dokter gigi di Rumah Sakit Gigi dan Mulut Universitas Jenderal Soedirman Purwokerto dengan nilai p 0,003. Pelatihan merupakan salah satu bentuk pembelajaran yang akan menghasilkan pengalaman belajar yang dapat menimbulkan perubahan perilaku, sehingga dengan pelatihan yang diberikan dapat merubah perilaku seseorang (Straus dan Syles dalam Notoatmodjo, 2007). Hal ini sejalan dengan penelitian Arlina (2015) yang melakukan penelitian kepada petugas IGD di RSM Ahmad Dahlan dengan hasil terdapat pengaruh pelatihan terhadap kepatuhan penggunaan alat pelindung diri. Sejalan puala dengan penelitian yang dilakukan oleh Haridi (2016) terhadap dokter gigi di Saudi Arabia bahwa terdapat hubungan antara pelatihan dengan kepatuhan penggunaan alat pelindung diri. Sebaliknya hasil penelitian ini tidak sesuai dengan penelitian yang dilakukan oleh Kartika (2014) menunjukan pelatihan penggunaan alat pelindung diri belum dapat meningkatkan yang menyatakan bahwa pelatihan menggunakan APD belum mampu untuk meningkatkan perilaku penggunaan alat pelindung diri.

Rumah Sakit Gigi dan Mulut Universitas Jenderal Soedirman Purwokerto menyelenggarakan pelatihan rutin tentang pencegahan dan pengendalian infeksi yang di dalamnya mencakup tentang penggunaan alat pelindung diri. Mahasiswa profesi sendiri sebelum menjadi masa studi di Rumah Sakit Gigi dan Mulut Universitas Jenderal Soedirman harus menjalani masa orientasi yang di dalamnya juga mencakup materi penggunaan alat pelindung diri. Pelatihan yang diberikan ini dapat menjadi bekal untuk menambah pengetahuan responden yang dapat meningkatkan perilaku penggunaan alat pelindung diri selama melakukan tindakan pelayanan kepada pasien.

Hubungan pengawasan terhadap kepatuhan penggunaan alat pelindung diri

Dari hasil analisis yang dilakukan, didapatkan hasil bahwa terdapat hubungan antara pengawasan yang dilakukan terhadap kepatuhan penggunaan alat pelindung diri pada mahasiswa profesi dokter gigi di Rumah Sakit Gigi dan Mulut Universitas Jenderal Soedirman Purwokerto. Hal ini sejalan dengan penelitian yang dilakukan oleh Yulita (2013) yang menyatakan bahwa terdapat pengaruh yang bermakna dari pengawasan yang dilakukan terhadap kepatuhan penggunaan alat pelindung diri perawat di Rumah Sakit Umum Daerah Provinsi Kepulauan Riau. Penelitian serupa juga dilakukan oleh Riyanto (2014) yang 
menyatakan bahwa terdapat hubungan antara pengawasan dengan kepatuhan perawat di Rumah Sakit Sari Asih Banten.

Menurut Green dalam Notoatmodjo (2007), faktor pengawasan dapat menambah motivasi dalam perubahan perilaku seseorang. Adanya pengawasan yang baik dapat menambah kesadaran diri untuk dapat membentuk perilaku seseorang sehingga pengawasan yang konsisten merupakan hal yang harus dilaksanakan oleh semua institusi. Rumah Sakit Gigi dan Mulut Universitas Jenderal Soedirman melakukan fungsi pengawasan melalui Tim Pencegahan dan Pengendalian Infeksi Rumah Sakit yang bertugas melakukan pengawasan berkala terhadap kepatuhan penggunaan alat pelindung diri seluruh civitas hospitalia di Rumah Sakit Gigi dan Mulut Universitas Jenderal Soedirman Purwokerto, termasuk kepada mahasiswa profesi dokter gigi. Pengawasan dilakukan secara rutin satu bulan sekali untuk mengawasi kepatuhan pelaksanaan pencegahan dan pengendalian infeksi termasuk kepatuhan dalam menggunakan alat pelindung diri. Pengawasan berkala ini juga tentunya memberikan motivasi bagi mahasiswa profesi dokter gigi untuk selalu patuh dalam menggunakan alat pelindung diri setiap melakukan tindakan kepada pasien.

\section{KESIMPULAN}

Variabel usia, pengetahuan, sikap, ketersediaan fasilitas, pelatihan dan pengawasan berhubungan positif dengan kepatuhan penggunaan alat pelindung diri pada mahasiswa profesi dokter gigi di Rumah Sakit Gigi dan Mulut Universitas Jenderal Soedirman Purwokerto. Sebaliknya variabel masa kerja tidak berhubungan dengan kepatuhan penggunaan alat pelindung diri pada mahasiswa profesi dokter gigi di Rumah Sakit Gigi dan Mulut Universitas Jenderal Soedirman Purwokerto.

Pihak manajemen rumah sakit dapat mengadakan sosialisasi berkala dan pelatihan rutin tentang Pencegahan dan Pengendalian Infeksi agar dapat meningkatkan pengetahuan mahasiswa profesi dokter gigi tentang pentingnya penggunaan alat pelindung diri. Pihak rumah sakit juga harus meningkatkan ketersediaan fasilitas alat pelindung diri serta melakukan pengawasan rutin terhadap kepatuhan penggunaan alat pelindung diri. Untuk pengembangan penelitian selanjutnya dapat ditambahkan variabel lain dan juga memperluas populasi responden pada seluruh mahasiswa profesi dokter gigi ataupun menambah jenis responden terhadap seluruh civitas hospitalia di Rumah Sakit Gigi dan Mulut Universitas Jenderal Soedirman Purwokerto.

\section{DAFTAR PUSTAKA}

Alharbi, G. Shono, N. Alballa, L. Alpuf, A. (2019). Knowledge, attitude and compliance of infection control guidelines among dental faculty members and students in KSU. BMC Oral Health Journal: Vol 19: 7.

Arlina, D., Ellafrina, O. (2015). Evaluasi Penggunaan Alat Pelindung Diri Pada Petugas Igd (Studi Kasus Di Rsm Ahmad Dahlan Kediri). Naskah Publikasi. Yogyakarta: Universitas Muhammadiyah Yogyakarta.

Atmoko, T. (2012). Standar Operasional Prosedur (SOP) dan Akuntabilitas Kinerja Instansi Pemerintah. Skripsi. Bandung: Universitas Padjajaran.

Azwar, A. (1983). Pengantar Ilmu Kesehatan Lingkungan, Jakarta: Penerbit Mutiara.

Balbeid, M. Rachmi, A. T. Alamsyah, A. (2018). Pengaruh pengetahuan dan sikap dokter dan perawat terhadap kesiapan berubah dalam menerapkan clinical pathway. Prodenta Journal of Dentistry: 2 (1): 98-107.

Baseer, M. A. Ansari, S. H. Alshamrani, S. Alakras, A. R. Mahrous, R. Alenazi, A.M. (2016). Awareness of droplet and airborne isolation precautions among dental health 
professionals during the outbreak of corona virusinfection in Riyadh city Saudi Arabia. $J$ Clin Exp Dent: 8(4):e379-87.

Dayakisni. Hudaniah. (2003). Psikologi sosial. Malang: UMM Press.

Depkes RI. (2009). Profil Kesehatan Indonesia. Jakarta: Departemen Republik Indonesia.

Depkes RI. (2008). Pedoman Manajerial Pencegahan dan Pengendalian Infeksi di Rumah Sakit dan Fasilitas Kesehatan Lainnya. Jakarta.

Ferdinand, A. (2011). Metode Penelitian Manajemen Pedoman Penelitian untuk Penulisan Skripsi, Tesis, dan Disertasi Ilmu Manajemen, Edisi 3, AGF Books, Semarang: Fakultas Ekonomika dan Bisnis Universitas Diponegoro.

Firmansyah, T.A. (2007). Pemeriksaan Bakteri Total Udara dan Kuman Staphylococcus aureus dalam Ruang Operasi di Rumah Sakit Umum Daerah Kota Semarang. Karya Tulis Ilmiah. Semarang: Universitas Diponogoro.

Gibson, J. L.. (1997). Organisasi dan Manajemen, Jakarta: Penerbit Erlangga.

Goje, M. Balami, A. D. Jarma, M. Dauda, S. (2018). Knowledge, Attitude, Self Efficacy and Practice of Standard Precaution Measures by Nursing and Midwifery Students in Damaturu, North-Eastern Nigeria. International Journal of Advanced Community Medicine: 1(2): 4146.

Haridi, K. H. Al-Ammar, A. S. Al-Mansour, M. I. (2016). Compliance withinfection control standard precautions guidelines: a survey among dental healthcare workers in Hail Region Saudi Arabia. J Infect Prev: Nov 2016; 17(6): 268-276.

Ibrahim, B.. (2009). Tingkat Kepatuhan Penggunaan Sarung Tangan Dalam Kaitan Standar Kewaspadaan Umum Bagi Petugas Laboratorium Klinik Kota Cilegon Tahun 2009. Skripsi. Jakarta: Fakultas Kesehatan Masyarakat Universitas Indonesia.

Kartika, D. S., Yustinus, D. A. W. (2014). Analisis Faktor Yang Berhubungan Dengan Kepatuhan Menggunakan Alat Pelindung Diri. Naskah Publikasi. Surabaya: Fakultas Kesehatan Masyarakat Universitas Airlangga.

Katherine, M., Patricia, A,. (2004), Psychiatric mental Health Nursing, St. Louis.

Labrague, L. J. Rosales, R. A. Tizon, M. M. (2012). Knowledge of and Compliance with Standard Precautions among Student Nurses. International Journal of Advanced Nursing Studies.

Laksmi, F. Budiantoro. (2008). Manajemen Perkantoran Modern. Jakarta: Penerbit Pemaka.

Masloman, A.P. Kandou, G.D. Tilaar, Ch. R. (2015). Analisis Pelaksanaan Pencegahan dan Pengendalian Infeksi di Kamar Operasi RSUD Dr. Sam Ratulangi Tondano. Jikmu 5(2) : 238-249.

Masyhuri, M. Z. (2008). Metodologi penelitian pendekatan praktis dan aplikatif. Bandung: PT Refika Aditama.

Moekijat. (2008). Manajemen Personalia dan Sumberdaya Manusia. Yogyakarta: BFFE.

Mubarak, dkk. (2007). Promosi Kesehatan. Yogyakarta: Graha. 
Mulyaningsih, Adhytyo. (2013). Reliabilitas Mempengaruhi Kepuasan Pasien Terhadap Pelayanan Kesehatan di salah satu Puskesmas Kabupaten Ngawi. Jurnal Kesehatan. 10 (2), 22-32. Surakarta : STIKES Aisyiyah.

Mulyanti. (2008). Faktor presdiposing, Enabling dan Reinforching terhadap Penggunaan Alat Pelindung Diri dalam Asuhan Persalinan Normal di Rumah Sakit Meuraxa Banda Aceh Medan. Tesis. Universitas Sumatra Utara.

Notoadmodjo, S. (2007). Promosi kesehatan dan ilmu perilaku. Jakarta: Rineka Cipta.

Notoatmodjo, S. (2014). Kesehatan Masyarakat : Ilmu dan Seni. Jakarta : Rineka Cipta.

Potter, Perry. (2010). Fundamental Of Nursing: Consep, Proses and Practice. Edisi I Vol. 3.

Putra, Mochamad. (2012). Hubungan Tingkat Pengetahuan dan Sikap dengan Perilaku Penggunaan Alat Pelindung Diri pada Mahasiswa Profesi Ilmu Keperawatan Universitas Indonesia, Skripsi, Jakarta: Fakultas Ilmu Keperawatan Universitas Indonesia.

Putri, K. D. S. Denny, Y. (2014). Analisis Faktor Yang Berhubungan Dengan Kepatuhan Menggunakan Alat Pelindung Diri. Artikel Penelitian. Departemen Keselamatan dan Kesehatan Kerja Fakultas Kesehatan Masyarakat Universitas Airlangga.

Riyanto. D. A. (2014). Faktor- Faktor Yang Mempengaruhi Kepatuhan Perawat Dalam Penggunaan Alat Pelindung Diri Di Rumah Sakit Sari Asih Serang Provinsi Banten. Jurnal. STIKES Santo Boromeus.

RSGM Unsoed. (2018). Laporan Indikator Mutu RSGM Unsoed. Purwokerto: RSGM Unsoed. Sailendra, Annie. 2015. Langkah-Langkah Praktis Membuat SOP, Cetakan Pertama, Trans Idea Publishing, Yogyakarta

Saputro, V. A. 2015. Hubungan Antara Pengetahuan Dan Sikap Dengan Penggunaan Alat Pelindung Diri (Apd) Pada Pekerja Di Unit Kerja Produksi Pengecoran Logam. Naskah Publikasi. Program Studi Kesehatan Masyarakat Fakultas Ilmu Kesehatan Universitas Muhammadiyah Surakarta.

Sihombing, F.D. (2014). Faktor - faktor yang mempengaruhi pemakaian alat pelindung diri (APD) pada pekerja "stimulasi" di unit penderesan PT Socfin Indonesia Tanah Besih Tahun 2014. Artikel penelitian. Medan: Fakultas Kesehatan Masyarakat Universitas Sumatera Utara.

Souza, R.A, Namen, F.M, Galan, J, Vieira, C, Sedano, H. (2006). Infection control measures among senior dental students in Rio de Janeiro State, Brazil: J Public Health Dent 66(4):282-4.

Sugiyono. (2012). Metode Penelitian Kuantitatif, Kualitatif, dan RND, Bandung: Alfabeta.

Supiana, N. (2013). Hubungan faktor predisposing, enabling, dan reinforcing dengan penggunaan APD pada bidang dalam pelayanan kebidanan di RSKIA Sadewa Yogyakarta tahun 2013. Artikel penelitian. Yogyakarta: Stikes 'Aisyiyah.

Wibowo, A.S. Suryani, M. Sayono. (2013). Hubungan karakteristik perawat dengan penggunaan sarung tangan pada tindakan invasif di ruang rawat inap RSUD Dr. H. Soewondo Kendal. Jurnal. Jurnal Ilmu Keperawatan dan Kebidanan 2013: 1(4): 1-9.

World Health Organization (WHO). (2009). WHO Guideline on Hand Hygiene in Health Care. Di akses dari :http://whqlibdoc.who.int.

Wuisan, C. Rampengan, S. H. Korompis, M. (2017). Factors related to the implementation of universal precautions by nurses in the inpatient unit (IRINA F) Prof. Dr. R. D. Kandou Central General Hospital Manado. Bali Medical Journal (Bali Med J): Volume 6: 68-72. 
Analisis Tingkat Kepatuhan Pemakaian Alat Pelindung Diri Mahasiswa Profesi Dokter Gigi Di Rumah Sakit Gigi Dan Mulut Unsoed

Zaenab, S.N, Zulhadi, Trisnantoro, L. (2013). Problem dan Tantangan Puskesmas dan Rumah Sakit Umum Daerah dalam Mendukung Sistem Rujukan Maternal di Kabupaten Karimun Provinsi Kepri Tahun 2012. Jurnal Kebijakan Kesehatan Indonesia: 2(4):189-201. 